\title{
6 \\ An Open Struggle of Redefinition
}

On May 1, 1957, the CCP launched another rectification campaign under Chairman Mao's direction. Unlike the one that had engulfed Yan'an during the early 1940s, which turned those whom he referred to as intellectuals into the targets of attack, the new campaign sought criticism of the party's governing performance from this category of people. Mao believed that the airing of criticism by intellectuals in the manner of "gentle breeze and mild rain" would help strengthen state-society relations and that the exercise was necessary to prevent political unrest such as those that had recently shaken socialist Poland and Hungary, in which students, workers, and others staged public protests, clashed with police, and demanded the removal of the government established by the communist parties. The new campaign followed eighteen months of high-level pronouncements and state measures aimed at improving relations with intellectuals, after they had been subjected to official disparagement and surveillance as well as reeducation and punishment since the 1949 revolution. Exclusive meetings with and encouragement from Mao and other party leaders gradually emboldened renowned writers, scientists, and other social notables to take the lead in providing critical evaluations of official policies, practices, and personnel. Professional workers, college students, and even factory hands, including some who were party members, then joined a growing protest at once condoned, encouraged, and to a large extent coordinated by the state. ${ }^{1}$ Dismayed by the hostility exhibited in some of the complaints and suggestions, the Mao leadership ended the campaign abruptly in early June and started to orchestrate counterattacks. The state launched the Antirightist Movement (Fanyou yundong) shortly afterward with the aim of punishing those who had spoken out or supported unacceptable views. The population of intellectuals suffered further loss of prestige and autonomy, while CCP rule slid further down the path of coercion, violence, and abuse. ${ }^{2}$

This chapter examines the 1957 Rectification Campaign and its aftermath in a new light-as an open struggle to redefine the intellectual as well as Chinese Communism. During those restive months, observations on challenges confronting the revolutionary project blossomed, and so did recommendations for 
change. Inside and outside the state, the crux of the debate was arguably the relations between the intellectual and Chinese Communism. Since 1949, economic nationalization and land reform had eroded the power of the urban and the rural economic elites. Mandated changes in the political, occupational, and educational systems had benefited industrial workers and other laborers, even though some of them were still dissatisfied, and for good reasons. Large numbers of scientists, writers, and other professional workers, however, had remained lukewarm toward CCP rule, especially after the Campaign to Wipe Out Hidden Counterrevolutionaries penetrated education, journalism, and other sectors and led to interrogations, demotions, imprisonments, and suicides. ${ }^{3}$ However fuzzy were the boundaries of the category of intellectuals, its members used the Rectification Campaign not only to air their criticisms of Chinese Communism and articulate alternative socialist visions; they tried to reconstruct their social identity to improve their status and influence and therefore what an intellectual was in Chinese society. The regime reacted to these challenges by expressing further its vision of the socialist project and the corresponding role of the intellectual.

Three major reinterpretations of the intellectual and Chinese Communism appeared. Championed by distinguished scholars and other social notables during the Rectification Campaign, the first reinterpretation was built upon the Confucian literati tradition as much as the official acknowledgment of widespread problems of competence in socialist governance. The scholars and notables portrayed intellectuals as experts and professionals outside the party who had the vital knowledge and experience to be its governing partner. They called for an expanded involvement of intellectuals in politics, production, and administration to save Chinese Communism from potential ruin. Another major reinterpretation was promoted mainly by college students. The proponents demanded that intellectuals redefine the socialist project in its totality. They combined contemporary ideas of democracy and equality with their reading of Marxism and Leninism to challenge how the revolutionary project had been formulated and executed by the Mao regime and the prerogative of the party to monopolize those tasks. In effect, the students and their allies redefined intellectuals as "legislators" of major social and political issues (to borrow an idea from Zygmunt Bauman) and architects of a different socialist China. ${ }^{4}$ When the Mao regime hit back, it drew on the Yan'an understanding of intellectuals and emphasized more than ever before the professional and political value of these people to Chinese Communism. The state introduced proposals to support the work and learning of professional workers and college students as well as to strengthen their ideological reeducation. Also stressed was the nurturing of industrial workers and others of underprivileged background into capable professional workers. The Mao regime pictured a surge of "red-and-expert" intellectuals who were dedicated to pushing Chinese Communism to new heights. 
The dominance of these perspectives not only indicates that the intellectual was quite objectified by the mid-1950s; it reveals that the intellectual had become the fulcrum with which the state and other forces organized their political visions and sought support. With each of the perspectives, symbolic boundaries were redrawn around the classification based on a specific set of experiences under the PRC. The scholars and notables who wanted to become partners in official governance had watched their influence and authority be eroded by CCP rule in general and workplace management by party cadres in particular. They represented themselves and other professional workers as intellectuals who were eager to serve the state and capable of improving Chinese Communism. The college students who advocated a complete overhaul of the socialist project combined political theories and ideas available in the university with the contemporary tradition of student protest. In their eyes, intellectuals were "spokesmen for enlightenment" ${ }^{5}$ with obligations to expose systemic injustice and steer China onto a superior socialist path. Drawing on its experience of revolution and governance, the Mao regime persisted in portraying professional workers and college students inside and outside the party as intellectuals as well as added workers with professional training to the social category. The regime's intention was to produce as many usable and reliable intellectuals as possible on behalf of Chinese Communism.

To be sure, the three perspectives on the intellectual and Chinese Communismintellectuals as state partners, as legislators, and as red-and-expert personnel-are analytical constructs. During the Rectification Campaign, analyses of political and social problems under the PRC and proposals to tackle the challenges were commonplace. Even more abundant were ritual affirmations of CCP rule, praises of Mao and other party leaders, highly emotional complaints, and self-deprecating remarks, or repertoires found in the innumerable ideological reeducation classes sponsored by the state since the 1949 revolution. As the campaign proceeded, individuals doubled down on, retreated from, and even altered their positions. When the Mao regime reasserted political control, elements of its arguments were reinterpreted at various levels of the state. Each of the constructs, however, captures political interests, beliefs, and imaginations that tended to coalesce together under the young PRC: the influence, respectively, of the Confucian, May Fourth, and Yan'an traditions of political thinking. Although the traditions support incompatible models of governance, they each envisage an important role for the educated. In addition, each construct reflects the location of its proponents in the socialist political economy. The college students who promoted the most radical approach to change were much farther from the center of power than were either the scholars and notables who wanted an improved part in governance and management or, closer still, the official and quasi-official spokesmen of the redand-expert ideal. 


\section{INTELLECTUALS AS STATE PARTNERS}

I've only been exerting sixty percent of my strength and energy [when at work]. It's not that I'm unwilling to do my best; there is no opportunity to do so, to become a soul mate of the party,

-FU YING, PROFESSOR OF CHEMISTRY AT PEKING UNIVERSITY, APRIL 27, $1957^{6}$

During the 1957 Rectification Campaign, leaders of various minor political parties approved by the state and scholars officially designated as higher (gaoji) intellectuals were chief proponents of the view that intellectuals and the state should work closely together to advance Chinese Communism. These scholars and notables generally had privileged access to CCP leaders and state assemblies as well as enviable positions and benefits approved by the state, because of its united front policy designed to secure cooperation and support from the elites outside the party. ${ }^{7}$ Before the campaign began nationwide, party leaders, including Mao, had invited these scholars and notables to forums to discuss official governance. ${ }^{8}$ During the campaign, the scholars and notables attended "airing-view" (mingfang) meetings sponsored by a variety of agencies, including central ministries, high-level CCP commissions, regional government offices, college party committees, and state-approved professional associations. They published their views on Chinese Communism in major newspapers and specialized journals. Because of their superior access to state affairs, the scholars and notables framed their criticism around "the most authoritative sources,"9 all of which were based on Mao's speeches delivered on the campaign's behalf. There is no need to repeat his famously positive assessment of class struggle or its declining significance under the PRC, other than his concern with the continual maltreatment of intellectuals by party cadres, or what he denounced as "the three evils of bureaucratism, subjectivism, and sectarianism" harming the development of the socialist project. ${ }^{10} \mathrm{His}$ criticism of the cadres became the foundation on which the scholars and notables pushed for involvement of intellectuals at all levels of governance and management, with the belief that this would strengthen fairness, justice, democracy, and efficiency nationwide. In other words, the proposal of the scholars and notables reflected the schism that had opened up between party cadres and other professional workers in the postrevolutionary workplace. If many cadres had escaped stigma by representing themselves as dependable revolutionaries overseeing petty-bourgeois intellectuals, the stigmatized now tried to redefine the meaning of the intellectual to reclaim their lost status and authority.

The scholars and notables invoked to different extents the Confucian tradition of literati in using their learning and wisdom to serve the state. Although the maneuvers signaled support of CCP rule, they involved critical disagreement with the official understanding of intellectuals. The Mao regime had attacked intellectuals for their alleged selfishness, apathy, and other "petty-bourgeois" 
and even "bourgeois" shortcomings, and considered these persons usable but unreliable when it came to developing Chinese Communism. For the regime, the Rectification Campaign of 1957 was merely another exercise that the state organized to tackle the undesirable values, ideas, and habits shared by intellectuals. The campaign offered intellectuals who were outside the party an opportunity to help its cadres, a good number of whom were deemed to be intellectuals, improve their work. The scholars and notables downplayed the regime's criticism of intellectuals, emphasizing instead their preparedness to serve the state as well as their untapped potential as a result of its unwise governing approaches. Huang Yaomian (1903-1987), a professor of Chinese language and literature at Beijing Normal University, was among those who recited this popular theme. In an essay published in People's Daily (Renmin ribao), the official organ, he stated that intellectuals were "bearers of the literati-official (shidafu) tradition" with "precious knowledge" acquired through "many years of labor" (laodong). The last phrase hinted at the discipline exhibited by intellectuals and their lack of connection to class exploitation, and therefore contradicted the official evaluation of such subjects. For Huang, intellectuals wanted badly to serve "the state and the country" and deserved respect, assistance, and direction from the authorities. ${ }^{11}$ Gong Canguang was the vice chancellor of Chongqing Teacher Training School as well as a member of the Sichuan Provincial Committee of the China Democratic League (CDL), a political party established during the Anti-Japanese War and operated under CCP auspices after 1949. He published a forceful defense of the political value of intellectuals for the Mao regime. He agreed with the official claim that a mutually expedient "employer-employee" relationship had been the primary dynamics between rulers and intellectuals before 1949. But he rejected the official view that intellectuals had been uninterested in politics, noting, instead, that they were knowledgeable and concerned about this dimension of social life through the ages. Even when they were "ruthlessly attacked" by the state and party cadres after 1949, they had been "perfectly happy" to study Marxist thought. He wanted the regime to adopt policies and practices that would help intellectuals recognize that they were "masters of their country" who could propose ideas to improve socialist development "without any future worries" of attacks and punishment. ${ }^{12}$ Feng Kexi (1922-2004) was another CDL member and an official in the Chongqing municipal government. He complained about the Mao regime's distrust of intellectuals and their abuse by party cadres. Unlike Huang and Gong, he argued that existing intellectuals were different from past generations of literati, who were derided by the regime as self-serving and corrupt. Intellectuals had made "substantial [political] improvements" before and more so after 1949, to the extent of parting with their wealth and risking their safety to "serve the people rather than the ruling classes." Nonetheless, he invoked the tradition of literati serving the state to counsel the cultivation of "friendship and contact" between intellectuals and party cadres, workers, and peasants as means to improve the 
involvement of imperfect and timid and yet loyal, talented, and dedicated intellectuals in the socialist project. ${ }^{13}$

The proposal that the state and intellectuals build a partnership to advance Chinese Communism was daring on another level: it undercut the official ideology of class struggle and decades of CCP denunciations of the complicity of intellectuals in this drama. For the Mao regime, the appointment of party cadres to authority positions after the 1949 revolution was as vital to the liquidation of the exploiting classes as land reform and nationalization of industry had been. Everyday management by veteran revolutionaries and other party cadres was the only means to bring the dictatorship of the proletariat to the local level. The setup was essential to keeping expropriated landlords and capitalists from regaining power through collusion with intellectuals, or to preventing the reproduction of the political and economic relations that these populations had shared before the revolution. The scholars and notables ignored and even challenged this official premise. They built upon Mao's recent observations on the diminishing significance of class struggle and his criticism of party cadres to argue against reliance on this population in governance and management. To the vice chancellor of Beijing Normal University, Fu Zhongsun, intellectuals were useful and reliable subjects. He stated that the official policy on intellectuals was "one of the CCP's biggest misjudgments in recent years." Attacking professors and other experts and professional workers as old-fashioned (jiu), bourgeois, or petty-bourgeois intellectuals led to widespread abuse against such persons and their distrust of the state, when "the era of class struggle" had already ended with the demise of landlords and capitalists and "the majority of intellectuals" had been supportive of the "goals of socialism and communism" of the state. ${ }^{14}$ Xu Zhongnian (1904-1981), a professor of French at the Shanghai Foreign Language Academy, took a comparatively subtle approach when criticizing the theory and practice of class struggle. He agreed with the official assessment that most intellectuals had "a dual character" (liangmian xing) under Chinese Communism - that is, they sometimes acted for and sometimes acted against the revolutionary project. However, this was also true with party cadres, because they, too, had come of age in "the old society" and had been influenced by its characteristic thoughts and habits. Even worse, Xu continued, many of the cadres had joined the CCP for self-serving purposes. Permitting the cadres to lord over and abuse intellectuals, especially those who deliberately stayed behind in China to contribute to Chinese Communism, would only harm its prospect. ${ }^{15}$ In short, Xu questioned whether party cadres were any more politically reliable than intellectuals as the Mao leadership assumed.

After the high tide of the Rectification Campaign subsided in June 1957, Minister of Food and Grain Zhang Naiqi (1897-1977) continued to promote his sanguine interpretation of class struggle under the PRC, until pressured by the state to repudiate what he had said. Zhang was a founder of the China National Democratic Construction Association (Zhongguo minzhu jianguohui), another 
political party that operated under CCP guidance after 1949, and a former businessman and college professor. While he acknowledged that class struggle is vital to any socialist revolution, he proclaimed that "no one [in China] wavers over the socialist path" anymore, not even the remnants of the capitalist class, who "cannot and will not rebel" against the CCP, still less return to power. Even when the state was gearing up to punish its critics, he defended critical viewpoints from airingview meetings and newspapers that had been labeled "counterrevolutionary" as mere "grumblings" from a few about their personal difficulties. Zhang continued to borrow from Mao when the Chairman had already changed his mind about the Rectification Campaign as a result of the avalanche of complaints against the state. Zhang noted that class struggle in general and ideological reeducation in particular had produced "tremendous results" for CCP rule since 1949, notwithstanding some "negative consequences" among party cadres, intellectuals, and others, such as frictions and mistrust and feelings of superiority and inferiority. Furthering "class cooperation" under CCP leadership, or the inclusion of marginalized intellectuals in official governance, would improve state-society relations and economic development as well as extend and deepen socialist consciousness across classes. ${ }^{16}$

Research has shown that the measures of political reform promoted by the scholars and notables were consistent with their recommendation of expanding the role of intellectuals in politics, production, and administration. The scholars and notables pressed for participation, voice, and authority under the existing framework of government. An important proposal was the strengthening of the political, legislative, and advisory functions of the National People's Progress (NPC) and the Chinese People's Political Consultative Conference (CPPCC), the high-level official bodies which had strong representations of scholars and other educated people outside the party but little practical influence over state affairs. Other important measures included the incorporation of members of these bodies into the investigation of wrongful convictions in previous political campaigns and the reduction of CCP involvement in everyday governance. ${ }^{17}$ A main vehicle with which the scholars and notables sought to realize these and other long-term changes was fazhi, which can be translated as rule of law. A negligible idea in the official discourse of the Rectification Campaign, fazhi has received little attention in research. ${ }^{18}$ The notion of rule of law, however, seemed no more nor less controversial to the scholars or notables compared to their other proposed reforms. That this was the case indicates further the unbridgeable ideological gap between the Mao leadership and the scholars and notables as well as the extent to which these people sought to redefine the intellectual and Chinese Communism.

The scholars and notables, especially those with legal training, wanted to use law to establish structural constraints on the behavior of the CCP and the state. They wanted to realign governance away from management by party cadres, from campaign-style violence and justice, and from institutionalized discrimination 
on the basis of class, politics, or other factors of personal background, especially against intellectuals. After 1949, the institution of law encountered dramatic reorganization but not standardization in terms of rules, procedures, or staff competence. ${ }^{19}$ Huang Shaohong (1895-1966), a former Guomindang high official, was one of those who complained about the low "cultural level" and poor knowledge of the party cadres in the legal field and the lack of oversight in areas from legislation, prosecution, and policing to verdicts, sentencing, and administration of penalties. He pressed for institutionalization of penal and civil codes, disciplinary codes for civil servants, economic laws, and regulations on organizations, among other instruments, to improve uniformity and transparency in the delivery of justice. ${ }^{20}$ His proposal, like others mentioned below, would work only when the legal field involved specialists and other educated people who had been excluded from it. The jurist Yang Zhaolong (1904-1979), who had been a prosecutor-general in the Guomindang government, similarly wanted promulgation of formal codes without further delay: "In many circumstances, ordinary people cannot tell what is legal from illegal, what a criminal offense is and the appropriate punishment and so on; even those involved in investigation, prosecution, and trials do not have a clear and uniform set of standards that they follow." He criticized the state's emphasis on the individual's acquiring the correct proletarian "standpoint, perspective, and work style," seeing this push based on official ideology as an impediment to using law broadly to advance democracy, stability, citizenship, and justice under CCP rule. ${ }^{21} \mathrm{Wu}$ Jialin (1926-), who headed the teaching-research team on Chinese constitutional law at People's University of China, stated that a lack of legal knowledge permeated even the highest CCP organs and resulted in widespread infringements against the 1954 Chinese constitution at all levels. He listed examples that included "black palaces and government offices" where officeholders had not gone through any proper appointment procedures. His recommendations to the leadership-strengthen the work of legislation and of legal education and research, act as a law-abiding model, and reorganize and clarify the roles of the party and the state-captured the legal reforms desired by the scholars and notables. ${ }^{22}$

The scholars and notables seldom promoted multiparty competition, direct election, or other sweeping changes to the existing political system. Instead, they wanted the CCP to adopt serious political, legal, administrative, and personnel reforms that would elevate first and foremost their participation in governance and management. Such a position reflected the close but unequal relations that the scholars and notables had shared with the party leaders under the PRC, as well as the intense official mobilization of these people to set examples in evaluating and criticizing official governance. The ideas and ideals of the scholars and notables betrayed their dismissiveness toward the official discourse of class and their disapproval of official denigration of intellectuals. In practice, the scholars and notables built upon Mao's dissatisfaction with party cadres to improve their own 
positions and those of the professional workers outside the party. The proposal from Minister of Transportation Zhang Bojun (1895-1969), a leader of two officially approved political parties, is a perfect example. He suggested that national issues be discussed and advised by such parties as well as by higher intellectuals and pertinent experts. He wanted reforms that would strengthen the advisory function of the NPC Standing Committee, the CPPCC, and the minor parties, all of these being establishments filled with educated people who had yet to acquire influence over state affairs. He did not discuss the role of workers or peasants in national political life, a ringing concern of the CCP since its inception, except to include "state-sponsored mass organizations" (renmin tuanti) together with the NPC, CPPCC, and minor political parties as a primary component in his proposed "political design department," a forum that would advise the leadership on all important matters. ${ }^{23}$ His recommendations were aimed at curbing rather than protecting the political participation of underprivileged populations.

In sum, the scholars and notables redefined intellectuals as experts and professional workers outside the CCP. This revision of the official view was borne out of a sense of frustration and concern about governance and management under the party, a material-cum-symbolic division between party cadres and ordinary educated people inside the workplace, as well as a protean tradition of Confucian thought. The scholars and notables emphasized the goodness of education for the individual and society and wanted the educated to be part of the governing elites effecting changes from within the state. The scholars and notables did not question the right of the CCP to rule, but disagreed with its disruption of the conventional order of prestige and influence. They did not oppose China's pursuit of a modern socialist society, but rejected the official endorsement of class interest and class struggle as, respectively, the basis of societal divisions and means of their unification. The future of Chinese Communism, they believed, hinged on the incorporation of intellectuals in political debates and deliberations as well as in governance and management. Their proposals embodied the Confucian preoccupation with hierarchy and harmony. ${ }^{24}$ Had the CCP leadership adopted the reforms proposed by the scholars and notables, Chinese Communism would involve patterns of value and authority quite familiar to the general population.

\section{INTELLECTUALS AS LEGISLATORS}

Peking University is the birthplace of the May Fourth movement. . . . We need to learn from our May Fourth elders the spirit of asking bold questions and forging daring creations, and to strive for truly socialist democracy and culture.

- A STATEMENT FRom THE INAUgural issue of THE SQUARE, A STUdent PUBLICATION AT PEKING UNIVERSITY, MAY 21, $1957^{25}$ 
In his 1987 book on intellectuals, Bauman describes the legislator as an enduring role that "men of letters" in Europe have played since the Age of Enlightenment. Here individuals claim intellectual authority on the basis of their expert knowledge and its alleged objectivity, arbitrate controversies related to the social order in highly public manners, and provide aesthetic, moral, and political judgments. They see themselves as having "a right (and a duty) to address the nation on behalf of Reason, standing above partisan divisions and earth-bound sectarian interests." ${ }^{26}$ During the 1957 Rectification Campaign, the role of the legislator was filled not so much by renowned scientists, writers, or artists as by college students. The leaders of these students were often from the distinguished Peking University (colloquially known as Beida). For decades, the campus had been a center of political protest and intellectual innovation and, by mid-century, one of the "most recognizable symbols of opposition to autocracy." ${ }^{27}$ Like the scholars and social notables discussed above, the students supported the building of a modern socialist China. But they challenged the philosophical, epistemological, and political justifications of CCP rule supplied by the Mao leadership. The protesters publicized their views in forms of posters, essays, poems, open letters, and speeches. Their idealized selfimage was that of an advocate of reason, equality, democracy, and justice, a bearer of the critical spirit of the May Fourth movement of the early twentieth century. ${ }^{28}$ For this reason, some students consecrated their political protest by naming it the May Nineteenth movement, after the date when the first protest poster appeared in Beida. ${ }^{29}$ In the weeks that followed, the protesters framed their criticism of the state and proposals for change around the intellectual generally in tangential ways. Given the exclusive education the students were receiving and, as we shall see, their erudition, it was hard for their peers and instructors, as well as for party cadres and state leaders, not to see that the students were redefining the intellectual with Chinese Communism through their protest.

Some student protesters presented themselves as authoritative interpreters of Marxist thought. They took aim at what they regarded as inaccurate CCP interpretations as well as at the people and organizations supporting those views, including Chairman Mao and People's Daily. One such protester was Beida student Tan Tianrong, a physics major who shot to fame during the Rectification Campaign. He produced a series of provocative and sometimes rambling essays, boldly titling them "poisonous weeds," a metaphor that Mao had employed to denigrate political ideas unacceptable to the party leadership. What Tan considered poisonous, however, was the extent to which Lenin and Stalin — and the CCP—-had misinterpreted Marxism and hence stifled its emancipatory potential. Drawing on the work of a professor at Nankai University, Tan contended that since Engels's death in 1895, the "revisionism" and "dogmatism" of Lenin and Stalin had "absolutely dominated" Marxist political philosophy, leading to single-party rule, systemic political discrimination, cults of personality, individualized attacks, and other forms of state 
abuse under the cover of the pursuit of communism. ${ }^{30}$ Tan criticized "More on the Historical Experience of the Dictatorship of the Proletariat," the influential essay published by the CCP in People's Daily in December 1956. The essay was the party's international response to the unexpected criticism of the recently deceased Stalin by Nikita Khrushchev, the head of state of the Soviet Union, as well as to the unrest in Poland and Hungary. ${ }^{31}$ The Mao leadership affirmed communist party rule as essential for maintaining working-class control in socialist countries, and indicated that official abuses, including the types of murder perpetrated by Stalin's regime, were preventable through the implementation of correct policies and methods of governance and the teaching and learning of appropriate work styles by officials. ${ }^{32}$ The leadership used the essay to support the launching of the Rectification Campaign. Tan criticized the essay for its "idealist" and "metaphysical" thinking and its incompatibility with dialectical materialism. ${ }^{33}$ The latter school of thought, which stresses the impact of material conditions on social consciousness, had been extolled by the Mao leadership as the epistemological basis of CCP rule, Marxism, and valid knowledge. In effect, Tan accused the leadership, the self-proclaimed arbiter of Marxist thought, of lacking understanding of its underlying philosophy. He attacked the leadership with terms that it had long used to discredit its ideological competitors (that is, revisionism, dogmatism, and idealism). He even predicted the failure of the campaign to improve statesociety relations. Yan Zhongqiang, another physics major at Beida, went further in his critical interpretation of Marxism and Chinese Communism. Using a combination of Kantian and Lockean emphasis on human sensibility, experience, and understanding, he argued that the "theory of materialism" underlying Marxism had been proven useless for and unscientific in the natural sciences: the theory is but a form of "religious belief" imbued with "class interests", like Christian, Buddhist, or other religious thoughts. While Yan applauded the use of the "sharp knife" of materialism by the proletariat in class struggle, he suggested that ruling communist parties had been exploiting this "entirely disposable" weapon, using it "to deceive and lord over the people." He expected that the people would rise up someday and teach the regimes a lesson. ${ }^{34}$

Other protesters combined their knowledge of Marxist thought and lived experience under CCP rule to dispute the official account of the class structure of the PRC and its alleged elimination of exploiting classes. No evidence suggests that the protesters had read Yugoslav dissident Milovan Djilas's 1957 treatise on the rise of a ruling class of party officials under communist political rule. ${ }^{35}$ Their understanding of the emergence of such a ruling class in China was probably inspired by Leon Trotsky's famous indictment against the Soviet system in The Revolution Betrayed, a Chinese translation of which was available by the early 1940 s. $^{36}$ Zhou Dajue, a lecturer at the Beijing Aviation Academy, brought up Lenin's and Engels's definitions of social class to contest Mao's recent observation that "non-antagonistic contradictions among the people" had replaced class struggle as the major form of 
political conflict on the Mainland. ${ }^{37}$ Zhou observed that a new class of "important personages in the party, government, and military" who wielded redistributive power had appeared. These people, he said, enjoyed unwarranted compensation and had committed brutally repressive acts, by which he probably meant unjust sentences meted out to critics of CCP rule. Furthermore, an organized circle (jituan) of party officials had begun to take shape with the aim of gaining economic, political, and other advantages over the rest of the population. ${ }^{38}$ For Zhou, class struggle was well and alive under the PRC, but the exploiters had changed. A history student at Beida, Pang Zhuoheng advanced his own class analysis which took into account "direct and indirect relations to the means of production" and "locations in production and distribution." He contended that CCP rule had produced six classes with different collective interests. Party officials and members formed the core of the "leadership class," and other classes, which included a class of intellectuals, were supportive of this leadership. However, even party leaders, like any members of the other classes, constantly struggled between following and transcending their self-serving habits and values. Pang's rejection of the claim that the CCP leadership represents the interests of the working class led him to conclude that the party could become counterrevolutionary, especially when it uses violence to suppress the socialist demands of the rest of the classes. ${ }^{39}$

An important outcome of their theoretical and analytical challenges against the official discourse of class, party, and revolution was that the protesters disputed whether China had established socialism based on the vision of Marx and Engels. Such skepticism was compounded by national publication of complaints about governing practices, including lack of due process, invasive surveillance, physical punishment, workplace abuses, wrongful convictions, and widespread discrimination in appointments and allocation of benefits and opportunities. ${ }^{40}$ Zhou Dajue articulated a popular view held by the protesters: the "three evils" of workstyles that the state identified as common among party cadres, as well as the cult of Mao and the appearance of new types of economic and political inequality, revealed the "strong feudal color" (nonghou de fengjian zhuyi secai) of the existing political system. ${ }^{41}$ Like "revisionism," "dogmatism," and "idealism," fengjian zhuyi (feudal thoughts) was a term that the CCP leadership had employed to attack its opponents and, especially, what it considered to be the obsolete and oppressive character of their ideas and conduct. Zhou deployed the term, instead, to indicate that the constitution of Chinese Communism was more traditional than revolutionary, and its governing practices were exploitative rather than emancipatory. In a similar vein, Beida mathematics student Qian Ruping suggested that Marxism-Leninism, public ownership, and collective ownership were misleading "shop signs" erected by the state, behind which economic exploitation persisted, as "some had taken control of the labor of others." 42 Lin Xiling (1935-2009), who studied law at People's University of China, became another leader of student protesters. She questioned whether the Soviet Union, from which the Mao regime 
borrowed its approach to socialist development, had actually become a Marxisttype socialist society. ${ }^{43}$ In her opinion, the Soviet Union, not to mention China, was at best in a "transitional period" toward socialism. ${ }^{44}$ The protesters' complaints against Chinese Communism, especially its philosophical basis, are not always comprehensible because of the speed with which the views were assembled during the protest as well as the competition for intellectual sophistication on college campuses. Yet there is little doubt that some students and instructors saw sweeping change as indispensable for building a genuinely socialist China.

The young protesters demanded institutional reforms to expand political participation, curb official abuses, and prevent the rise of a new exploiting class. Central to their demands were competitive elections. While the Mao regime feared that such elections would lead to the reintroduction of capitalist and other forms of exploitation and ultimately destroy Chinese Communism, the protesters held the opposite view. They believed that the postrevolutionary elimination of the capitalist and landowning classes as well as grave disparities in earnings from the political economy had created conditions for deepening working-class rule through competitive elections-and that such elections were vital to thwarting officials becoming unaccountable to the laboring masses. ${ }^{45}$ Despite limited official news coverage of political reforms in Yugoslavia, ${ }^{46}$ the introduction there of self-government to replace centralization of political and economic management was widely hailed by the protesters as an example of socialist democracy. ${ }^{47}$ In a letter to a worker at Beida's printing house, Long Yinghua, a philosophy major at the university, captured the depth of political participation that some protesters wanted to achieve through competitive elections. Among other things, this blueprint, which echoed the concept of socialist democracy in Lenin's famous 1917 essay The State and Revolution, recommended that the factory choose its managers and other leaders through direct elections. The elected would be subject to recall and would be responsible for implementing collective decisions..$^{48}$ Reacting against the existing official control of elections, others demanded that candidates should explain their principles and policies publicly before the elections, and that the elected report their work regularly to the workforce. ${ }^{49} \mathrm{~A}$ general belief was that direct election should be extended to the political realm, including the selection of provincial heads and members of all levels of the people's congresses..$^{50}$ Some even suggested that voting should be included in the process of recruitment and expulsion of CCP members to permit popular control of the membership..$^{51}$ This last suggestion implies that the protesters wanted competitive elections to be implemented broadly in the countryside, too, although their views rarely mentioned conditions in rural areas. ${ }^{52}$

If adopted, the reforms proposed by the protesters would reduce the CCP's role in governance and management dramatically. Ma Yunfeng, who studied at the Beijing Aviation Academy, envisioned that the party's domination of state and society through multiple layers of party cells would give way to "a system of 
decision by the majority." Within workplace management, party cadres and nonparty personnel would have equal status and authority. If no cadre occupied management positions, nonvoting delegates would be assigned to enable the party to publicize, explain, and provide leadership on policies and directions..$^{53} \mathrm{~A}$ biology student at Beida, Jiang Xingren, saw the CCP becoming one of the political parties competing for management posts in the self-governing workplace. ${ }^{54}$ No one seems to have commented directly on the future role of Mao, but with the popularity of the notion of competitive elections and the criticism of cults of personality, it was evident that the protesters did not want him to wield supreme authority. Beida law student Li Shaolin, who supported electoral democracy at all levels, suggested what appears to have been the desired change when he proposed that the National People's Congress become the highest ruling body through which "the people supervise and monitor the state apparatus and its personnel," an arrangement that had been legally but not actually in effect. ${ }^{55}$

Unlike the scholars and notables introduced earlier in the chapter, the young protesters did not redraw the boundaries of the category of intellectuals explicitly. Nonetheless, they redefined what it meant to be an intellectual as much as the scholars and notables did, especially for their own generation of college students. The protesters did not see themselves as heirs of Confucian literati, still less a cog in the state machine of socialist development. They placed critical reason above the political and class hierarchy enforced by the party and its demand for political submission and ideological reeducation. The protesters promoted personal autonomy, social equality, popular participation, and competitive election as preconditions for a truly socialist China-and considered CCP rule its main obstacle. They were inspired by those who had led the May Fourth movement decades before. When we consider content and context together, it is clear that the protesters also borrowed from the critical political analyses of the intervening years and demonstrated exceptional political courage. As Edmund Fung has noted in his study of Chinese political thought, non-Marxist scholars continued to "rethink, reevaluate, and reformulate the Chinese past and articulate visions of Chinese modernity" before $1949 .{ }^{56}$ During the Rectification Campaign, the protestors reintroduced into the public realm key political issues debated between the May Fourth movement and the CCP takeover of China, including the role of the state and political parties, law and constitutionalism, and individual rights and liberties. Their goal was to promote democratic values and institutions as means to prevent socialist development from being ravaged by what they saw as political despotism and state violence under the PRC. Unlike May Fourth or other political activists of the Republican era, these protesters confronted not ineffective ruling regimes with limited capacity to police and punish, but an unprecedentedly powerful state which had penetrated the workplace, controlled livelihoods, exacted conformity, and even executed large numbers of "counterrevolutionaries." Even taking into account relentless official appeals for criticism of the state during the 
campaign, it is clear that the protesters stood up against a proven dictatorship and pointed toward another alternative path of socialist development.

\section{INTELLECTUALS AS RED-AND-EXPERT PERSONNEL}

In order to establish a fine socialist society, the party and the state have issued a call to intellectuals. Within ten years, the working class will have its own vast army of intellectuals. Let us work hard to reform ourselves, study and learn, and become working-class intellectuals.

-AN Editorial StATEMENT, WENHUi DAILY, OCTOBER 28, 1957

After abruptly ending the Rectification Campaign, the Mao regime orchestrated the Antirightist Movement to attack and punish critics of the CCP and the state, an episode that has been well documented. ${ }^{57}$ Here I focus on the official understanding of intellectuals expressed between July 1957 and January 1958, before the gravely anti-intellectual and ultimately disastrous Great Leap Forward engulfed China. ${ }^{58}$ Succinctly captured by the phrase "red and expert" (you hong you zhuan) and its variants, which began to saturate the media nationally during the last months of 1957, the official understanding reflected how the party leadership had conceptualized the intellectual since the Yan'an days of Chinese Communismwith a newfound but short-lived optimism. ${ }^{59}$ We have seen the Yanan approach to intellectuals in action in the last three chapters. On the one hand, the Mao regime sought to harness knowledge and skills for the revolutionary project as well as to protect it from any "petty-bourgeois" and "bourgeois" influence, or the agenda and behavior of writers, journalists, professors, and other educated people. On the other hand, the regime was determined to provide professional and educational opportunities to members of the underprivileged to enable them to become proficient in political, technical, and administrative work. After the Rectification Campaign, the regime reaffirmed commitment to this approach, even though it had produced deep tensions and divisions within Chinese society. The regime proposed that a refinement of the approach would deliver to Chinese Communism large numbers of useful and reliable intellectuals.

On a theoretical level, the red-and-expert extension of the Yan'an approach to intellectuals shares some strong similarities with the writings of the Italian Marxist Antonio Gramsci (1891-1937). He believed that the communist party must play the leading role in the transition to socialism. Large numbers of "organic intellectuals" must serve as conduits of socialist values and builders of the state and other robust socialist institutions. The development of such intellectuals, however, presents many challenges, because unbecoming values, beliefs, and habits from the prerevolutionary society will continue to loom large after the socialist revolution. On one level, Gramsci argued, the state must assimilate "existing categories of intellectuals" into the socialist project, because their knowledge and reputations 
are valuable assets for governance and development. The targets include what he called traditional intellectuals (e.g., writers, artists, clergies) and what Lenin referred to as "bourgeois experts" (such as industrial managers, research scientists, and urban planners). On another level, the state must provide training to "indigenous representatives of the proletariat," people who have been deprived of educational and other opportunities. These individuals must be taught to combine Marxist thought with personal experience of labor and poverty to help "transform the contradictory consciousness of the working class," or the tendency of its members to sometimes support and sometimes resist change, into "revolutionary self-awareness."6o After the Rectification Campaign, the Mao regime invested further in the political and technical education of party cadres, professional workers, college students, and labor and peasant representatives. Of the three perspectives on the intellectual discussed in this chapter, the red-and-expert ideal was the only one pursued by the regime-and that, only for a very short while.

During the Antirightist Movement, the Mao leadership promoted further rationales and methods to intensify the ideological reeducation of professional workers and college students. Because members of these groups had complained about CCP rule and received wide support from their peers, the state now derided these populations in the media as "bourgeois intellectuals" (zichan jieji zhishifenzi), that is, intellectuals who wanted to restore class exploitation across China. ${ }^{61}$ As the state punished those whom it singled out as "rightists," it also advanced proposals to rectify how professional workers and college students related to "the laboring masses." The official goal was to turn such workers and students into "intellectuals of the working class" (gongren jieji zhishifenzi). Like before, the state argued that this would be a long and arduous process. Although thought reform, mass campaigns, and other forms of ideological reeducation had helped intellectuals improve their appreciation of Chinese Communism, "the overwhelming majority" still did not understand the "thoughts and sentiments" of workers or poor peasants, let alone embrace their class interest as the interest of all. Among intellectuals, including those who had joined the party, residual belief in bourgeois ideology, property, and individualism was commonplace, and manifested as selfcenteredness, careerism, condescension toward workers and peasants, and other undesirable habits and dispositions. ${ }^{62}$

For the Mao regime, most important for the future success of the ideological reeducation of intellectuals was their self-determination. "Intellectuals must make up their minds, even if it is painful, to unite with the laboring masses, starting with becoming one with the masses and integrating the individual into the collective. They must draw a clear distinction between labor and exploitation and between who and what to love and hate. They must establish a correct understanding between the collective and the individual and work hard to overcome and guard against individualism." ${ }^{33}$ Repeated abundantly in the media, this kind of demand on scientists, writers, and others epitomizes what Timothy Cheek 
observes as the twin premises of governance under Mao. Epistemological elitism held that "legitimate answers" to ethics, politics, history, and development could only be provided by the CCP leadership; attitudinal fundamentalism put forth "attitudes as the prime mover of behavior" of all kinds. ${ }^{64}$ The Mao regime was confident with its existing approach to intellectuals. As class subjects, journalists, engineers, college students, and other educated people were politically unreliable, but not irredeemable.

Because the Mao regime used Marxist philosophy to argue that political consciousness is intimately connected to practical activity, a host of organizational measures that would supposedly assist intellectuals to turn over a new leaf was quickly affirmed. The measures, some of which were already familiar to the general public, included the deepening of self-criticism and mutual criticism among professional workers, the use of peasants and workers and their firsthand experiences to help with the ideological reeducation of schoolteachers and students, and sending writers to "the midst of the masses" and assigning college graduates to stints of labor training to help these intellectuals understand the difficult lives of workers and peasants and their hopes and perseverance. ${ }^{65}$ Within six months after the Rectification Campaign's conclusion, tens of thousands of writers, editors, schoolteachers, and officials from Beijing, Shanghai, and other places had traveled to various provinces to live and work with workers and peasants. ${ }^{66}$

For the Mao leadership, equally important was to rectify the relationship between intellectuals and science, or how to support the enterprise further on behalf of Chinese Communism. A major complaint from professors and others had been the state's heavy-handedness and, especially, the vesting of management authority in ill-trained party cadres. A Yan'an revolutionary with a degree from Tsinghua University, Yu Guangyuan (1915-2015), worked at the CCP Department of Propaganda during the 1950s. Shortly after the Rectification Campaign, in an article in People's Daily, he explained official thinking in a socialist country "like ours in which the development of science has been comparatively backward." Yu reaffirmed that central planning and organization of research were necessary to thwart localized decision-making based on self-serving reasons. But he also pledged state support of universities and research institutes and mentioned the development of industrial zones and the introduction of science and industry to ethnic minority areas. He emphasized the limited role that the party foresaw for itself in the realm of science. The CCP wanted neither "to take up scientific research" nor "to arrange work [in such detail] as scientists do with their [research] assistants." The party, instead, would provide leadership in three areas: putting forward principles, policies, and plans to facilitate research and setting up the necessary systems of work; winning scientists over and giving them education in Marxism and Leninism; and mobilizing personnel and institutional support to improve working conditions. To foster scientific development, he remarked, the state would sometimes need to reassign scientists in ways requiring some to apply 
their expertise in related intellectual areas, move to other geographical regions, and even temporarily endure taxing working and living conditions. ${ }^{67}$ To support scientific progress, the State Council soon approved four proposals related to the purchase of library books, reference works, equipment, and chemical reagents, partly because "the absolute majority" of suggestions recently voiced by scientists during the Rectification Campaign "should be affirmed." Overall, the state noted that improving scientific performance would be a "complex and painstaking" task, but essential for the future. ${ }^{68}$

Jiang Nanxiang (1913-1988), a veteran CCP member, was the chancellor of Tsinghua University, which specialized in science and engineering education. His opening address to a campus symposium on science and his commencement speech to the graduating class of 1957 suggest that the "red-and-expert" ideal was stressed across colleges. During the symposium, he strongly criticized "rightists" and intellectuals similar to what other authorities did, before addressing "bourgeois" habits and thinking in his workplace: "Quite a few [faculty still] emphasize scientific research in slanted and disconnected manners, seeing it as the only noble work above everything else." Some faculty used science for personal advancement and belittled production and the laboring masses; others sneered at student instruction, administrative work, and thought reform for diverting their time and energy away from research. However, Jiang did not want research on his or other campuses to be downgraded, because it was of "utmost importance" to higher education. Rather, he wanted research to be strengthened to the extent that all instructors who had mastered teaching content and techniques would place scientific research on their "daily agendas." Moreover, he wanted research to be redirected to serve public goals, of which he named two: producing "a national army of scientific and technical personnel" and contributing to "national construction." The first would require faculty to improve their research and teaching "in a complementary way." The second would mean developing theory, not for its own sake, but to connect it to the practical needs of the country. ${ }^{69}$

In his commencement speech, Jiang warned Tsinghua graduates against their "individualism." He complained that 503 graduates had requested to be assigned to a university, a research institute, a design department, or other comfortable professional establishments, while only 83 had listed factories, mines, or other demanding sites as their choices. Over half of the graduates wanted to stay in Beijing; a total of 296 had asked for special consideration based on health or family reasons; only 16 were open to all assignments; and merely 2 had volunteered to work in the underdeveloped and formidable northeast region. Jiang chided the graduates for their selfish calculus and insisted that they "happily accept any assignment from the state." ${ }^{70}$ He supported the assignment of college graduates to labor training to help them understand the socialist spirit. By the fall of 1957, Tsinghua faculty and students had begun to travel to nearby communes to assist in harvesting crops. ${ }^{71}$ All the while, Jiang did not doubt that colleges should continue to improve "living 
and learning conditions" and help to turn as many students as possible into scientific and other experts. ${ }^{72}$

Based on its red-and-expert ideal, the state continued to promote professional education for former workers and peasants, as well as for party cadres of such backgrounds. As before, it was assumed that these individuals had a high potential to comprehend class struggle and the purpose of Chinese Communism. With appropriate training, they would combine their professional knowledge and life experience to serve the socialist project, becoming what the state called "worker-peasant intellectuals" (gongnong zhishifenzi). Their professional and intellectual elevation would help to alleviate the entrenched separation and inequality between mental and manual labor in Chinese society. In practice, the state kept on expanding literacy training, unconventional enrollments in schools and colleges, and part-time education and other skill-based classes. Tsinghua University admitted hundreds of young soldiers and other atypical students to its regular academic programs in 1958. ${ }^{73}$ The enrollment of cadres and students of underprivileged backgrounds in Shanghai's higher education was projected to increase from 28 percent in 1957 to at least 40 percent in 1962 and 60 percent in 1967. ${ }^{74}$ In Sichuan Province, leaders of colleges and universities wanted to expand all sorts of programs through increasing the enrollment of such students and using "minimum admission standards" to replace preferential enrollment for those who had achieved the same score as other candidates. ${ }^{75}$

At the national level, proposals were available on how to tackle challenges confronting the training of CCP cadres and others of underprivileged background within higher education. Lu Ge (1913-1988), a veteran party member and official at the Ministry of Education, insisted that proper procedures be established to enroll those of genuinely underprivileged background, because others had misused the opportunities. Preference in admission should be given to underprivileged candidates once they had achieved the required academic standards. To smooth their transition from work and address their academic underpreparedness, additional attention would be needed to place these persons in appropriate classes, including use of separate training programs, and to ensure proper financial and academic assistance. Family circumstances should be considered when assigning graduating students to new positions. The abruptly ended Rectification Campaign had revealed that existing students and professors resented the admission of unconventional candidates to colleges and, especially, elite universities. ${ }^{76} \mathrm{Lu}$ wanted the state to refute opinions that unconventional enrollees should be educated outside existing campuses. He wanted colleges and universities to tackle everyday discrimination against such enrollees. ${ }^{77}$

During its short-lived prominence, the red-and-expert ideal of the intellectual was an auspicious as well as ominous sign for Chinese Communism. It was auspicious because the Mao regime, though confronted and embarrassed by unprecedented complaints from those whom it considered intellectuals, planned and implemented policies and measures not only to change the minds of these people, 
but also to turn out others with knowledge and skills to advance the revolutionary project. The official pursuit of an educated, industrialized, and socialist China continued. But it was also ominous, because what was proposed or implemented to achieve the ideal involved little philosophical, political, and hence institutional innovation compared with what had already been done. The Mao regime simply reaffirmed its Yan'an approach to intellectuals, which had helped the CCP seize state power but was recently proven to be politically incendiary and socially divisive under the PRC.

On a theoretical level, the proposed and implemented measures exposed key differences between the CCP's Marxism and Gramsci's Marxism. The divergence provides a valuable window on why the Mao regime would turn against the category of intellectuals shortly afterward by denigrating the value of formal education during the Great Leap Forward and then launching a wholesale attack on such people during the Cultural Revolution. The Mao leadership saw the development of what Gramsci called organic intellectuals as vital to furthering Chinese Communism. Unlike Gramsci, however, the regime never once imagined using these persons to build "egalitarian social relations and democratic political forms" to support the socialist project. ${ }^{78}$ Instead, the leaders continued to consecrate themselves as proletarian revolutionaries, define most educated people as unreliable intellectuals, and rely on state tutelage to attain a unifying governing structure and culture with the CCP on top. Gramsci was aware that top-down cultivation of organic intellectuals may empower the latter to the extent that they would pursue their own political agendas. But he "was clearly willing to live with such risks" rather than embrace the attempt "to impose socialism from above."79 The imposition, he believed, would breed bureaucracy or tyranny or both at the expense of democracy. Not only did the Mao regime share no such reservations; even as it promoted the red-and-expert ideal, the state continued to vilify and dominate those whom it labeled intellectuals and even singled out some of these people for prosecution, labor reform, and other kinds of punishment. In retrospect, the ideal was the last gasp of the Yan'an approach to intellectuals under the PRC.

The 1957 debate on the intellectual and Chinese Communism reveals the full extent of their impact on each other under the early PRC. What the socialist project had become was inseparable from how it had defined the intellectual and from the institutional and political consequences that followed. Where the project would go depended on its redefinition of the intellectual and the roles and responsibilities assigned to this subject. With each of the perspectives delineated above, important questions about China's transition to a supposedly improved socialist society were unanswered. The young protesters who wanted to reinvent the socialist project, for example, failed to address why competitive elections based on the ideas and qualifications of the individual would serve to overcome the entrenched divide between mental and manual labor, let alone prevent the emergence of new 
types of social inequality. The protesters also did not explain why CCP leaders and cadres would accept a greatly reduced role in governance and management or facilitate the expansion of political participation in all areas. Did the protesters want a violent revolution against CCP rule? How would official violence be used in the new society? Likewise, the scholars and notables who sought to be state partners did not clarify why elevating or returning scientists, lawyers, and other experts to positions of authority would improve the political or economic prospect of traditionally underprivileged populations. What did these experts share in their backgrounds that made them fit to promote socialist values and habits? What was the place of workers and other laborers in such a socialist society? The issues that the state elided in its counterargument are equally obvious. How would the intensification of ideological reeducation improve the socialist consciousness of professors, writers, or others, given the deep dissatisfaction that they had already shown with CCP rule? How would the professional education and empowerment of select members of the underprivileged affect their loyalty to the latter population? And what role in governance would the party play after creating an abundance of red-and-expert personnel?

Notwithstanding their incompleteness, the three perspectives on the intellectual and Chinese Communism are evidence that alternative directions of socialist development continued to exist after 1949. The perspectives were each based on a critique of existing political and social conditions. They addressed important concerns such as freedom, justice, equality, democracy, education, science, and productivity under the PRC. They received support from different sections of the general population, which indicate that they were not products of blithe utopianism, but of burgeoning movements for social change. We will never know how China would have fared had any of the perspectives become the foundation of a national agenda of socialist development. Even had such a journey taken off, it would have been filled with challenges, complications, and setbacks. However, it is difficult to imagine that the collective experience of the alternative would have been as traumatic and deadly as that which unfolded afterward with the Great Leap Forward and the Cultural Revolution sponsored by the Mao regime. After all, each of the perspectives embraced as political and moral principles some combination of critical reason, personal autonomy, technical competence, and collectivism as well as shared governance, class cooperation, rule of law, and scientific development. In contrast, what the state promoted in the following decade was the disparagement of science and education, the cult of Mao, class struggle, and a search for class enemies. These official principles would lead to false imprisonment and torture on a mass scale as well as starvation, murders, mob rule, collective killings, and tens of millions of fatalities. ${ }^{80}$ The next chapter will look at reinterpretations of the intellectual between the late 1950 s and the early 1960 s and the central role that they played in the devastating atrocities. 